J. Clin. Chem. Clin. Biochem.

Vol. 26, 1988, pp. 271-276

(C) 1988 Walter de Gruyter \& Co. Berlin - New York

\title{
Measurement of Activation Energy of $\gamma$-Glutamyltransferase as a Marker for Enzyme Heterogeneity
}

\author{
By J. Delanghe, M. De Buyzere, I. De Scheerder, R. Wieme \\ Faculty of Medicine - Dept. of Clinical Chemistry, University of Ghent, Belgium \\ C. Trendelenburg, J. Kruse-Jarres
}

Klinisches Chemisches Institut, Katharinen Hospital Stuttgart, Bundesrepublik Deutschland and

\section{U. Faust}

Institut für Biomedizinische Technik, Universität Stuttgart, Bundesrepublik Deutschland

(Received March 5, 1987/January 4, 1988)

Summary: In order to detect differences between various multiple forms of $\gamma$-glutamyltransferase, the activation energy was measured. In the serum of patients with liver diseases, activation energy was measured. In the serum of patients with liver diseases, activation engergy of the serum enzyme is higher than in normal individuals $(41.9 \pm 1.2$ vs. $38.9 \pm 1.5 \mathrm{~kJ} / \mathrm{mol}, \mathrm{p}<0.05)$. Neuraminidase treatment resulted in a reduction of activation energy. Various multiple forms of serum $\gamma$-glutamyltransferase, as prepared by lectin affinity chromatography (concanavalin A, Ricinus communis I and II, wheat germ agglutinin) showed activation energy differences between binding and nonbinding fractions. Similar results were observed in seminal plasma $\gamma$-glutamyltransferase, when patients with accessory gland infection were compared with a reference population. Our results suggest that the activation energy depends upon differences in the carbohydrate part of the enzyme. The low $\gamma$-glutamyltransferase activation energy of tissue extracts increased significantly after butanol extraction and was then comparable with serum activation energy values, which suggests that lipid-binding is a factor in activation energy variation. In most cases, $\gamma$-glutamyltransferase activities measured at a certain temperature can be easily converted to a corresponding activity at another temperature, but in severe liver disease significant errors may be introduced when simple temperature conversion factors are used.

\section{Introduction}

$\gamma$-Glutamyltransferase (EC 2.3.2.2) is a membranebound enzyme, present in many human organs (1). Serum $\gamma$-glutamyltransferase activity, however, is accepted to be mainly of hepatic origin and serum $\gamma$ glutamyltransferase activity determinations are commonly used in clinical chemistry as a sensitive marker for hepatic damage. Human seminal fluid also contains large quantities of the enzyme and $\gamma$-glutamyltransferase activity measurements are used for following prostatic function (2). In the routine clinical laboratory, the activation energy of the $\gamma$-glutamyltransferase reaction is assumed to be constant and tem- perature conversion factors are commonly used to convert enzyme activities from one temperature into another. In contrast to many other enzymes $\gamma$-glutamyltransferase has no typical isoenzymes (genetically determined differences in protein structure). Variations in the carbohydrate part of the enzyme and especially differences are mainly due to an increased activity of glycosyltransferases and the uptake of serum $\gamma$-glutamyltransferase by hepatic receptors. Both factors are affected by liver disease (6). Also macromolecular $\gamma$-glutamyltransferase forms have been noticed, in which the enzyme is attached to lipoproteins (7) or even entire membrane fragments 
(8). Activation energy of an enzyme can be obtained by measuring the rate of the enzymic reaction at two different temperatures. Activation energy values of enzymes can be altered by small variations in molecular structure, as shown for creatine kinase $(9,10)$.

In the present study, the activation energy of $\gamma$-glutamyltransferase from various sources was measured very accurately and variations in the activation energy of the enzymes were correlated with the clinical diagnosis of the patients and compared with the structural variation of the enzyme.

\section{Materials and Methods}

\section{Patients}

Activation energy of $\gamma$-glutamyltransferase was determined in a group of apparently healthy blood donors, all with normal serum $\gamma$-glutamyltransferase activities $(n=20 ; 10$ males, 10 females; age $36.8 \pm 11.4 \mathrm{y}$ ) and in a group of patients with various liver and pancreatic diseases with elevated serum $\gamma$ glutamyltransferase activities $\left(>100 \mathrm{U} / 1,25^{\circ} \mathrm{C}\right)(n=20,11$ males, 9 females; age $54.3 \pm 12.9 \mathrm{y}$ ). Reference urine material was taken from healthy laboratory staff members $(n=5)$. Seminal plasma, obtained from men $(n=6)$ without clinical or laboratory signs of accessory gland infection, served as a reference for seminal plasma activation energy values. This group was compared with a group of 6 patients with proven accessory gland infection. Tissue extracts of liver, pancreas, kidney, prostate, vesiculae seminales, and brain were obtained during autopsy and prepared according to Seiffert (11). Blood was obtained by venipuncture and was allowed to clot at room temperature for a least $10 \mathrm{~min}$. Serum was obtained after centrifugation (10 $\mathrm{min}, 1300 \mathrm{~g}$ ).

\section{Methods}

$\gamma$-Glutamyltransferase activity was determined according to Szasz using $L-\gamma$-glutamyl-3-carboxy-4-nitroanilide as a substrate (12) with commercial reagents from Merck (Darmstadt, FRG). Activation energy (E act) of $\gamma$-glutamyltransferase was calculated according to the Arrhenius equation

$$
\ln k_{1} / k_{2}=\mathrm{E} \text { act } / \mathrm{R}\left(1 / \mathrm{T}_{1}-1 / \mathrm{T}_{2}\right) \text {. }
$$

The standard temperature interval for determination of the apparent activation energy was $298.14-308.14 \mathrm{~K}$ (25.00$35.00^{\circ} \mathrm{C}$ ). The activation energy was assayed with the apparatus as described by Hagelauer (13), consisting of a Beckman spectrophotometer DU-7 (Beckman Instruments, Irving, CA, USA), equipped with an ultrasound thermostat (Huber Kältemaschinen, Offenburg, FRG). An 80 SDT professional matrix computer (Mostek, Neuhausen-Fildern, FRG) was used for the control of the temperature and evaluation of the kinetic data. Concanavalin A, Ricinus communis I and II, and wheat germ agglutinin lectins covalently bound to Sepharose 4B gel were obtained from E\&Y Laboratories (San Mateo, CA, USA). Lectin affinity chromatography of $\gamma$-glutamyltransferase was performed according to a modification of the method of Köttgen (8) with a start and equilibration sodium acetate buffer of $0.1 \mathrm{~mol} / \mathrm{l}\left(\mathrm{pH} 6.0,1.0 \mathrm{mmol} / \mathrm{I} \mathrm{CaCl}, 1.0 \mathrm{mmol} / \mathrm{l} \mathrm{MgCl}_{2}, 1.0\right.$ $\mathrm{mmol} / \mathrm{l} \mathrm{MnCl}_{2}, 1.6 \mathrm{mmol} / \mathrm{l} \mathrm{NaN} \mathrm{N}_{3}, 5 \mathrm{~g} / \mathrm{l}$ Triton $\left.\mathrm{X}-100\right)$. Neuraminidase from Clostridium perfringens, $\alpha-L$-fucosidase from beef kidney, methyl $\alpha$ - $D$-mannoside, $D$-galactose and $\mathrm{N}$-acetyl glucosamine were from Sigma (St. Louis, Mo, USA). All other chemicals were of analytical grade from Merck (Darmstadt, FRG). Neuraminidase (EC 3.2.1.18) treatment was performed by adding $0.5 \mathrm{ml}$ of serum to an equal amount of acetate buffer $(0.1 \mathrm{~mol} / 1, \mathrm{pH} 6.0)$ containing $10 \mathrm{mU}$ of neuraminidase and incubating the sample for 16 hours at $37^{\circ} \mathrm{C}$. Butanol extraction was performed according to Beck (14).

\section{Statistical analysis}

Statistical analysis was carried out by means of the Wilcoxon test. Correlation analysis was performed by means of a Spearman test (rank correlation coefficient).

\section{Results}

\section{Temperature interval}

Arrhenius plots for $\gamma$-glutamyltransferase activation energy were shown to be linear in the temperature interval between $15^{\circ} \mathrm{C}$ and $35^{\circ} \mathrm{C}$. For further measurements, activation energy was calculated from activities obtained at 25 and $35^{\circ} \mathrm{C}$. Repeated cycles of dissipation of ultrasound energy $\left(7 \times 75 \mathrm{~J} / \mathrm{cm}^{3}\right)$ and cooling to $19^{\circ} \mathrm{C}$ of native serum samples did not result in any change of enzyme activity or activation energy. At the ultrasonic energy level used (2.1 $\mathrm{W} / \mathrm{cm}^{3}$ ), no activation or denaturation of the enzyme was observed.

\section{Analytical precision}

Activation energy of a $\gamma$-glutamyltransferase pool $\left(160 \mathrm{U} / 1\right.$ at $\left.25^{\circ} \mathrm{C}\right)$ was determined at various dilutions. The following coefficients of variation were obtained, calculated from 5-fold determinations: pool $160 \mathrm{U} / 1$ $(40.8 \mathrm{~kJ} / \mathrm{mol}, \mathrm{CV} 0.9 \%)$; pool $80 \mathrm{U} / 1(40.7 \mathrm{~kJ} / \mathrm{mol}$, $\mathrm{CV} 1.2 \%)$; pool $30 \mathrm{U} / \mathrm{l}(41.1 \mathrm{~kJ} / \mathrm{mol}, \mathrm{CV} 1.7 \%)$. Storing serum and seminal fluid samples for 1 week at $4{ }^{\circ} \mathrm{C}$ or for 4 weeks at $-21^{\circ} \mathrm{C}$ did not significantly affect the activation energy values.

\section{Activation energy of $\gamma$-glutamyltransferase} from tissue samples and body fluids

Comparative data on $\gamma$-glutamyltransferase activation energies from various butanol-extracted tissues and body fluids are summarized in table 1 . The activation energy of serum and seminal plasma $\gamma$-glutamyltransferase of patients with liver diseases or accessory gland infection was significantly higher $(p<0.05)$ compared with the references. Neuraminidase treatment of both tissue extracts and body fluids does not significantly change the activation energy. Differences in the activation energy of serum $\gamma$-glutamyltransferase were further studied in a group of patients with elevated serum $\gamma$-glutamyltransferase activities and suffering from various liver diseases. Table 2 depicts serum $\gamma$-glutamyltrans/erasc enzyme activity and activation energy in these groups of pa- 
Tab. 1. Activation energy ( $\mathrm{E}$ act) of $\boldsymbol{\gamma}$-glutamyltransferase from various tissues and body fluids before and after neuraminidasc treatment. Tissue extracts werc obtained after butanol extraction procedures.

\begin{tabular}{|c|c|c|c|}
\hline Sources & $n$ & $\begin{array}{l}\text { Before neuraminidase treatment } \\
\mathrm{E} \text { act }(\mathrm{kJ} / \mathrm{mol})\end{array}$ & $\begin{array}{l}\text { After neuraminidase treatment } \\
\mathrm{E} \text { act }(\mathrm{kJ} / \mathrm{mol})\end{array}$ \\
\hline \multicolumn{4}{|l|}{ Tissues } \\
\hline Liver & 3 & $39.1(37.6-40.7)^{*}$ & $38.5(37.0-39.9)$ \\
\hline Pancreas & 3 & $40.2(39.0-41.2)$ & $39.4(38.3-40.4)$ \\
\hline Kidney & 3 & $39.7(38.4-41.3)$ & $38.9(37.4-40.2)$ \\
\hline Prostate & 3 & $39.5(37.4-41.5)$ & $38.4(37.1-39.8)$ \\
\hline Vesiculac seminales & 3 & $39.3(37.3-41.7)$ & $38.7(37.0-40.9)$ \\
\hline Brain & 3 & $39.5(38.0-41.0)$ & $38.8(37.1-40.8)$ \\
\hline \multicolumn{4}{|l|}{ Body fluids } \\
\hline Urine & 5 & $39.6(37.9-41.5)$ & $39.0(37.4-40.9)$ \\
\hline \multicolumn{4}{|l|}{ Serum } \\
\hline - refcrence & 20 & $38.9(37.2-42.7)$ & $38.5(36.9-40.6)$ \\
\hline - liver disease & 12 & $41.9(40.4-44.5)^{x}$ & $39.4(37.9-42.0)$ \\
\hline \multicolumn{4}{|l|}{ Seminal plasma } \\
\hline - refercnce & 6 & $40.8(39.5-42.0)$ & $39.1(37.9-40.6)$ \\
\hline - accessory gland infection & 6 & $41.5(40.9-42.6)^{x}$ & $39.4(38.0-41.4)$ \\
\hline
\end{tabular}

* Mcan and range.

${ }^{*} p<0.05$, pathologic groups compared with the references.

Tab. 2. Activation energy and enzyme activity of scrum $\gamma$ glutamyltransferase in various liver and pancreatic discases, compared with a reference population.

\begin{tabular}{lrll}
\hline Patient groups & $n$ & $\begin{array}{l}\text { Activation } \\
\text { energy } \\
(\mathrm{kJ} / \mathrm{mol})\end{array}$ & $\begin{array}{l}\text { Enzyme } \\
\text { activity } \\
\left(\mathrm{U} / 1,25^{\circ} \mathrm{C}\right)\end{array}$ \\
\hline Liver metastasis & 5 & $41.6 \pm 0.7^{*} \cdot \chi$ & $192 \pm 59$ \\
Ethanolic liver disease & 5 & $40.3 \pm 0.7 \chi$ & $335 \pm 292$ \\
Viral hepatitis & 4 & $40.2 \pm 1.6 \chi$ & $167 \pm 45$ \\
Extra-hepatic obstruction & 4 & $39.8 \pm 2.1$ & $251 \pm 130$ \\
Pancreatitis & 3 & $41.3 \pm 2.4 \chi$ & $433 \pm 172$ \\
Reference population & 20 & $38.9 \pm 1.5$ & $16 \pm 7$ \\
\hline
\end{tabular}

* Mean $\pm S D$

$\chi \mathrm{p}<0 . \overline{05}$, patient group compared with reference population.

tients, in comparison with a reference population. In all types of liver pathology studied, except extrahepatic obstruction, the activation energy of serum $\gamma$ glutamyltransferase was significantly higher $(p<0.05)$ than in the reference population. Total serum $\gamma$-glutamyltransferase activity and activation energy were shown to be independent (Spearman rank correlation coefficient of 0.226 ). When following the activation energy during the course of neuraminidase treatment $\left(16 \mathrm{~h}, 25^{\circ} \mathrm{C}\right)$ of pathological serum samples, a nearly linear decrease of activation energy of $\gamma$-glutamyltransferase was observed, until substrate depletion was reached. Figure 1 shows the time course of the effect of neuraminidase treatment of these samples ( $10 \mathrm{mU}, 0.5 \mathrm{ml}$ serum) on $\gamma$-glutamyltransferase activity. In contrast to neuraminidase treatment, digestion of $\gamma$-glutamyltransferase with fucosidase did not result in significant changes in the activation energy of these samples. In the group of pa-

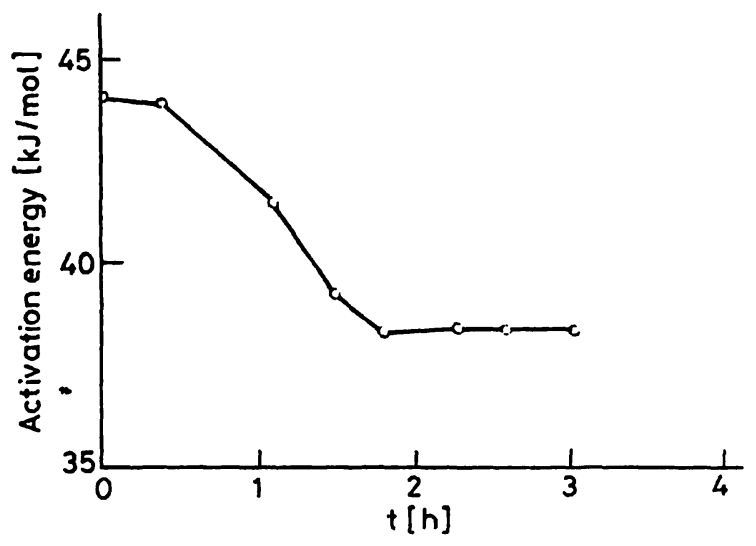

Fig. 1. Decrease of activation energy of serum $\gamma$-glutamyltransferase during neuraminidase treatment.

tients with accessory gland infection, activation energy values were found to be significantly higher $(p<0.05)$ as compared with the reference group $(41.5$ \pm 0.5 vs $40.8 \pm 0.8 \mathrm{~kJ} / \mathrm{mol}$ ). Neuraminidase treatment of seminal plasma $\gamma$-glutamyltransferase showed similar results to those obtained for serum $\gamma$-glutamyltransferase.

\section{Lectin affinity chromatography}

By means of lectin affinity chromatography towards concanavalin A, two groups of $\gamma$-glutamyltransferase multiple forms can be separated: a non-binding (sialic acid rich) and a binding (sialic acid poor) form. Sialic acid-rich fractions were found to have significantly higher $(p<0.05) \gamma$-glutamyltransferase activation energy values. Serum and seminal plasma $\gamma$-glutamyltransferase froms with an affinity towards both galactose recognizing lectins (Ricinus commumis lectins I 
Tab. 3. Activation energy of binding and nonbinding fractions of serum and seminal plasma $\gamma$-glutamyltransferase obtained by several forms of lectin affinity chromatography.

\begin{tabular}{|c|c|c|c|c|}
\hline Lectins & $n$ & Major sugar specificity ${ }^{+}$ & $\begin{array}{l}\text { Activation energy } \\
\text { Serum }(\mathrm{kJ} / \mathrm{mol})\end{array}$ & $\begin{array}{l}\text { Activation energy } \\
\text { Seminal plasma }(\mathrm{kJ} / \mathrm{mol})\end{array}$ \\
\hline $\begin{array}{l}\text { Concanavalin } A \\
\text { binding fraction } \\
\text { nonbinding fraction }\end{array}$ & $\begin{array}{l}5 \\
5\end{array}$ & $\begin{array}{l}\text { glucose, mannose, } \\
\text { and related } \\
\text { structures }\end{array}$ & $\begin{array}{l}39.8 \pm 0.8^{x} \\
46.2 \pm 3.0^{*}\end{array}$ & $\begin{array}{l}40.9 \pm 1.0 \\
47.5 \pm 2.2^{*}\end{array}$ \\
\hline \multicolumn{5}{|l|}{ Ricinus communis I } \\
\hline $\begin{array}{l}\text { binding fraction } \\
\text { nonbinding fraction }\end{array}$ & $\begin{array}{l}4 \\
4\end{array}$ & galactose & $\begin{array}{l}38.1 \pm 1.1 \\
40.4 \pm 1.2\end{array}$ & $\begin{array}{l}38.5 \pm 1.6 \\
38.8 \pm 1.6\end{array}$ \\
\hline \multicolumn{5}{|l|}{ Ricinus communis II } \\
\hline $\begin{array}{l}\text { binding fraction } \\
\text { nonbinding fraction }\end{array}$ & $\begin{array}{l}4 \\
4\end{array}$ & $\begin{array}{l}\text { galactose, } \\
\text { galactosamine }\end{array}$ & $\begin{array}{l}38.2 \pm 1.1 \\
40.2 \pm 1.8\end{array}$ & $\begin{array}{l}38.6 \pm 1.6 \\
38.8 \pm 1.8\end{array}$ \\
\hline $\begin{array}{l}\text { Wheat germ agglutinin } \\
\text { binding fraction } \\
\text { nonbinding fraction }\end{array}$ & $\begin{array}{l}4 \\
4\end{array}$ & $\begin{array}{l}\text { N-acetyl- } \\
\text { glucosamine }\end{array}$ & $\begin{array}{l}37.1 \pm 7.1 \\
42.2 \pm 4.1 *\end{array}$ & $\begin{array}{l}39.4 \pm 0.8 \\
43.7 \pm 1.0^{*}\end{array}$ \\
\hline
\end{tabular}

${ }^{*} p<0.05$

+ Major sugar specificities according to Delanghe et al. (19)

${ }^{\times}$Mean $\pm S D$

Tab. 4. Activation energy ( $E$ act) of $\gamma$-glutamyltransferase of serum and several tissues after extraction with butanol.

\begin{tabular}{llll}
\hline Source & $n$ & $\begin{array}{l}\text { Before butanol } \\
\text { extraction } \\
\text { E act }(\mathrm{kJ} / \mathrm{mol})\end{array}$ & $\begin{array}{l}\text { After butanol } \\
\text { extraction } \\
\text { E act }(\mathrm{kJ} / \mathrm{mol})\end{array}$ \\
\hline Serum (ref. pop.) & 5 & $38.8 \pm 1.6^{\mathrm{x}}$ & $39.5 \pm 1.7$ \\
Kidney & 3 & $39.0 \pm 1.6$ & $38.7 \pm 1.8$ \\
Liver & 3 & $33.5 \pm 1.8$ & $39.1 \pm 1.4^{*}$ \\
Pancreas & 3 & $34.9 \pm 1.9$ & $40.2 \pm 1.1^{*}$ \\
\hline
\end{tabular}

$\times$ Mean $\pm \mathrm{SD}$

$* p \leqslant 0.05$

and II) showed lower activation energy values than the fractions which were not retained by these lectins. Analogous results were obtained with the $\mathrm{N}$-acetylglucosamine specific wheat germ agglutinin. Table 3 summarizes the results of serum and seminal plasma $\gamma$-glutamyltransferase activation energy determinations of binding and non-binding fractions obtained by lectin affinity chromatography towards concanavalin A, Ricinus communis lectins I and II, and wheat germ agglutinin.

Effects of lipids on the activation energy of $\gamma$-glutamyltransferase

Comparison of results of $\gamma$-glutamyltransferase activation energy in serum and tissue extracts before and after butanol extraction are given in table 4 . In liver and pancreas tissue extracts, a significant decrease in activation energy values $(p<0.05)$ was observed, in contrast to kidney extracts and serum which showed comparable values before and after the extraction procedure. Effects of triacylglycerols were studied by adding a serum pool with poor $\gamma$-glutamyltransferase activity (4 U/l) containing $12.1 \mathrm{mmol} / \mathrm{l}=10.6 \mathrm{~g} / \mathrm{l}$ of triacylglycerols to $\gamma$-glutamyltransferase-rich serum $(585 \mathrm{U} / \mathrm{l})$ with a low triacylglycerol $(0.64 \mathrm{mmol} / \mathrm{l}$ $=560 \mathrm{mg} / \mathrm{l})$ content. After this treatment, no significant changes were observed in activation energy. Effects of LDL (beta)-cholesterol were evaluated by adding LDL-rich serum (LDL-cholesterol $7.5 \mathrm{mmol} / 1$ $=2900 \mathrm{mg} / \mathrm{l}, \gamma$-glutamyltransferase $10 \mathrm{U} / \mathrm{l})$ to serum obtained from a patient with hypobetalipoproteinaemia (LDL-cholesterol $0.98 \mathrm{mmol} / 1=380 \mathrm{mg} / 1, \gamma-$ glutamyltransferase $45 \mathrm{U} / \mathrm{l}$ ). LDL-cholesterol did not significantly influence the activation energy values of $\gamma$-glutamyltransferase.

\section{Discussion}

The values for the activation energy, as determined with the present technique, are somewhat higher than those cited earlier in the literature (15). Similar differences were obtained when the activation energies of creatine kinase (10) and other enzymes (13) were measured with this technique. In contrast to conventional techniques, ultrasound heating permits the terminal equilibrium to be reached very rapidly and accurately. When the enzyme activities are measured, temperature variations are within $0.03 \mathrm{~K}$. This accurate temperature control is required to achieve a precision of $2 \mathrm{~kJ} / \mathrm{mol}$ or less (which is a necessity when relative small differences like the ones observed in $\gamma$ glutamyltransferase are studied). In the various normal tissue samples studied, no significant differences in $\gamma$-glutamyltransferase activation energy were no- 
ticed. The observed values correspond well with the serum $\gamma$-glutamyltransferase values obtained in the reference population. In the patients with liver disease, higher values of the $\gamma$-glutamyltransferase activation energy are found. These results suggest a dissociation between catalytic activity and mass concentration of the enzyme. Similar results have been observed, making use of radioimmunoassay techniques in patients with liver disease (16). The lowering of the activation energy obtained after neuraminidase treatment suggests that the presence of sialic acid can be regarded as a steric hindrance for the active site of the enzyme. This result is confirmed by the finding of lower activation energies in sialic acid-poor forms of $\gamma$-glutamyltransferase, obtained by concanavalin A chromatography. In normal individuals, the relative binding capacity towards concanavalin A columns is almost $100 \%$. In liver disease, serum $\gamma$-glutamyltransferase gets more sialylated $(4,5)$, resulting in a decreased binding of $\gamma$-glutamyltransferase. Hypersialylation of $\gamma$-glutamyltransferase can be regarded as a mechanism for increasing the activation energy of $\gamma$ glutamyltransferase. The linear plot observed when neuraminidase was allowed to digest the terminal sialic acid residues suggests that the decrease in activation energy is correlated with the amount of sialic acid present on the molecule, so the differences in activation energy obtained after neuraminidase digestion (ranging from 0.8 to $5.5 \mathrm{~kJ} / \mathrm{mol}$ ) are proportional to the amount of sialic acid attached to the molecule. After neuraminidase treatment, however, differences between the various $\gamma$-glutamyltransferase samples are still present, suggesting that the activation energy is also influenced by factors other than sialic acid content. The differences observed between the $\gamma$-glutamyltransferase activation energies from the samples obtained by chromatography against the other lectins (Ricinus communis lectin I and II, wheat germ agglutinin) suggest that the activation energy depends partly upon differences in galactose and hexosamine content. These results are in agreement with recent studies $(6,17-20)$ showing differences in the galactose, hexosamine and fucose content of the $\gamma$-glutamyltransferase carbohydrate chain between normal and pathological samples, especially in patients with malignant diseases. The biochemical nature of these effects is however very complex, because changes caused by increased activities of glycosyltransferase acting on proximal parts of the carbohydrate chain induce secundary changes on more distal regions. Similar changes are observed in seminal fluid $\gamma$-glutamyltransferase, which is also characterized by a variation in its carbohydrate part (19).

Serum $\gamma$-glutamyltransferase activation energy is not affected by changes in VLDL and LDL concentration. In tissue extracts however, butanol extraction increased the activation energy values, suggesting that the membrane-bound $\gamma$-glutamyltransferase is characterized by lower activation energy values than the serum enzyme. $\gamma$-Glutamyltransferase from butanolextracted tissue samples shows activation energy values comparable with the ones obtained for the serum enzyme. From a clinical point of view, activation energy measurements show significant differences between normal and pathological samples, but do not allow differential diagnosis of liver disease. As the information obtained by activation energy measurements partly overlaps with total $\gamma$-glutamyltransferase activity, the determination of $\gamma$-glutamyltransferase activation energy is not a suitable technique for routine clinical chemical purposes. When comparing total $\gamma$-glutamyltransferase activities measured at 25 and $37^{\circ} \mathrm{C}$, errors due to variations in activation energy are usually small, as a difference of $1 \mathrm{~kJ} / \mathrm{mol}$ corresponds to an error of only $1.8 \%$. Significant errors can arise only in samples with very aberrant activation energies of $\gamma$-glutamyltransferase, which occur in severe liver diseases. When measuring enzyme activities of various multiple forms however, e.g. in severe liver disease, results obtained at 25 and $37^{\circ} \mathrm{C}$ may differ as much as $10 \%$ because of differences in activation energy.

\section{Acknowledgement}

The authors wish to thank Prof. Dr. Kolb (Blutzentrale Stuttgart) for the help in providing the serum samples of the reference population. Seminal plasma samples were given by Dr. Comhaire (State University of Ghent, Department of Endocrinology). The helpful discussions of Dr. Nedder were highly appreciated. Dr. Ing. Anaudov and Dipl. Ing. Joppek are thanked for carrying out the necessary modificalions of the equipment.

This work was supported by the DAAD (Deutscher Akademischer Austauschdienst).

\section{References}

1. Nemesanzky, E. \& Lott, J. (1985) Clin. Chem. 31, 797803.

2. Rosalki, S. B. \& Rowe, J. A. (1977) Life Sci. 20, 152-155.

3. Jaken, S. \& Mason, M. (1978) Proc. Natl. Acad. Sci. USA $75,1750-1753$.

4. Köttgen, E. \& Gerok, W. (1976) Klin. Wochenschr. 54, $439-444$.

5. Lilja, H., Jeppson, J. O. \& Kristensson, H. (1983) Clin. Chem. 29, 1034-1037.

6. Delanghe, J., De Buyzere, M., De Scheerder, I., Claeys, L. \& Wieme, R. (1987) Clin. Chim. Acta 162, 311-318.

7. Wieland, H., Bernhard, R., Baggio, G., Müller. P. \& Seidel, D. (1977) Eur. J. Clin. Invest. 7, 243. 
8. De Broe, M., Borgers, M. \& Wieme, R. (1975) Clin. Chim. Acta 59, 369-372.

9. Hagelauer, U., Faust, U., Trendelenburg, C., Kruse-Jarres, J.. Rudolph, T. \& Both, A. (1983) J. Clin. Chem. Clin. Biochem. 21, 874-876.

10. Wevers, R., Hagelauer, U., Stein, W., Bohner, J., Faust, U., Van Landeghem, A. \& Soons, J. (1985) Clin. Chim. Acta 148, 197-210.

11. Seiffert, U., Siede, W., Welsch, G. \& Oremek, G. (1984) Clin. Chim. Acta 144, 17-27.

12. Szasz, G., Weimann, G., Stähler, F., Wahlefeld, A. \& Persijn. J. (1974) J. Clin. Chem. Clin. Biochem. 12, 228.

13. Hagelauer, U. \& Faust, U. (1985) Biomed. Technik 30 , $264-271$.
14. Beck, P. (1978) Ann. Clin. Biochem. 15, 151-155.

15. Szasz, G. (1974) Z. Klin. Chem. Klin. Biochem. 12, 166170.

16. Masuike, M., Ogawa, K., Kitahara, T., Murata, A., Matsuda, K. \& Kosaki, G. (1983) Ann. Clin. Biochem. 20, $247=250$.

17. Huseby, N. \& Eide, T. (1983) Clin. Chim. Acta 135, $301-$ 307.

18. Yamaguchi, N., Kawai, K. \& Ashihara, T. (1986) Clin. Chim. Acta 154, 133-140.

19. Delanghe, J., Comhaire, F., De Buyzere, M. \& Vermeulen, L. (1985) Int. J. Androl. 8, 186-192.

20. Tsuchida, S., Yamazaki, T., Camba, E., Morita, T., Matsue, H., Yoshida, Y. \& Sato, K. (1985) Clin. Chim. Acta 152, 17-26.

J. Delanghe

UZ, Dept. of Clinical Chemistry, 2B2

De Pintelaan, 185

B-9000 Gent 